\title{
Papyrus, Forest Resources and Rural Livelihoods: A Village Computable General Equilibrium Analysis from Northern Zambia
}

\author{
Steven Gronau*, Etti Winter, Ulrike Grote \\ Institute for Environmental Economics and World Trade, Leibniz University of Hannover, Hannover, Germany \\ Email: *gronau@iuw.uni-hannover.de
}

How to cite this paper: Gronau, S., Winter, E. and Grote, U. (2018) Papyrus, Forest Resources and Rural Livelihoods: A Village Computable General Equilibrium Analysis from Northern Zambia. Natural Resources, 9, 268-296.

https://doi.org/10.4236/nr.2018.96017

Received: May 9, 2018

Accepted: June 25, 2018

Published: June 28, 2018

Copyright (c) 2018 by authors and Scientific Research Publishing Inc. This work is licensed under the Creative Commons Attribution International License (CC BY 4.0).

http://creativecommons.org/licenses/by/4.0/

\begin{abstract}
Papyrus is increasingly suggested as an alternative bioenergy source to reduce the pressure on forest ecosystems. However, there are few studies on the economic viability of papyrus wetlands and the benefits for local communities. We construct a village Computable General Equilibrium (CGE) model to examine whether papyrus harvesting and processing has the potential to improve local livelihoods and simultaneously counteract pressure on local forest resources. We apply the CGE model to a village in northern Zambia where overexploitation of forest resources to produce energy from firewood and charcoal poses a serious problem. The analysis is based on survey data from 105 households collected in 2015. The model results show that papyrus briquetting would be a possible alternative biofuel and that this technology improves household income and utility through labor reallocations. Higher opportunity costs lead to households switching from firewood extraction and charcoal production activities to papyrus harvesting and processing to produce bioenergy. Replacing energy supplies from firewood and charcoal with papyrus briquettes results in substitution effects between forest land and wetland and thereby reduces the pressure on local forest resources. The CGE approach allows for an economy-wide ex-ante analysis at village level and can support management decisions to ensure the success of papyrus bioenergy interventions.
\end{abstract}

\section{Keywords}

Papyrus, Bioenergy, Forest Resources, Village Computable General Equilibrium Model

\section{Introduction}

Biomass is the primary source of energy for over $80 \%$ of households in sub-Saharan 
Africa (SSA) [1]. It is predominantly used in the form of charcoal or fuelwood, mainly for cooking and heating [2] [3]. However, the bulk of fuelwood supply is informally obtained from natural forests impeding current efforts to promote more sustainable wood production [4]. In many areas, harvesting of forest resources is not sustainable and has led to the fragmentation and degradation of forest ecosystems [2] [5] [6]. An estimated 40\% rise in the demand for bioenergy by 2040 will further increase the pressure on forests [4]. At current extraction levels, many areas could be exhausted within the next two decades [5]. It is therefore essential to identify alternative bioenergy sources to reduce current unsustainable practices. One largely unrecognized yet significant source of biomass is tropical wetlands [7]. They belong to the most productive ecosystems globally [7] and show high rates of net primary productivity comparable with high-input, intensively managed agricultural systems [8] [9].

Wetlands cover approximately $7 \%$ of Africa [10], and many of the permanently flooded areas are dominated by papyrus swamps (Cyperus papyrus $L$.). The geographical extent of papyrus wetlands is not known exactly, but the major ecosystems are up to several thousand $\mathrm{km}^{2}$ in size and can be found in Sudan, Tanzania, Uganda, Kenya, DR Congo, Botswana, Zambia and others [11]. Papyrus is a $\mathrm{C}_{4}$ photosynthetic sedge native to rivers, flooded and peripheral wetlands of central, eastern and southern Africa [11]. Plant culms are the main aboveground vegetative structure, which are topped by an umbel. The value of standing aerial biomass is relatively stable with individual culms being present in multiple age classes throughout the year [8] [12]. Culms reach heights of up to 5 meters and the life cycle ranges between 5 and 12 months [12] [13]. The $\mathrm{C}_{4}$ photosynthesis makes papyrus wetlands extremely productive, outcompeting most other aquatic plant species and resulting in almost pure stands [8] [14] [15].

The recognition of the importance of wetlands is not new. Globally, 169 parties, including 50 African member states, have joined the Ramsar Convention on Wetlands to protect and conserve wetlands (https://www.ramsar.org/) whose importance can be understood within the framework of ecosystem services [16] [17] [18]. For example, Morrison et al. [19] identified 27 subgroups of benefits from the papyrus wetlands of Lake Naivasha and Lake Victoria in Kenya, which they classified according to the categories of provisioning, regulating, cultural and supporting services defined by the Millennium Ecosystem Assessment [20]. Papyrus wetlands are important habitats for birds, fish and wildlife [11] [21], significant carbon sinks [22] [23], provide wastewater treatment [24], flood protection [24] [25] and are biodiversity hotspots [26]. Moreover, they deliver important ecosystem services through their biogeochemical processes (e.g. nitrogen flows) and their local and regional hydrological cycle and climate regulation functions [10] [27]. Zambia joined the Ramsar convention in 1991. The country has 8 sites designated as Wetlands of International importance (Ramsar sites), such as Lake Mweru-wa-Ntipa and Lake Tanganyika in the Northern Province (https://www.ramsar.org/). 
Historically, papyrus was used for producing paper in ancient Egypt, Greece and Rome [28] [29]. At present, papyrus wetlands directly support millions of rural livelihoods especially in SSA by providing agricultural opportunities and livestock feed [30] [31] as well as drinking water [32]. Papyrus biomass is widely used for fences, roofs, crafts, rafts, household utensils, furniture and mats, but also as a fuel source [12] [33] [34] [35]. It can therefore have a positive impact on household income and provide grounds for various livelihoods in rural regions [36] [37].

The high rates of productivity in papyrus wetlands [9] [38] [39] highlights the potential of this plant as a bioenergy source [7]. Previous studies confirm the use of papyrus as a domestic fuel used by local communities living throughout the plant's geographical range: along the banks of the Nile in times of ancient Egypt [40]; within the Hula wetland of Israel [41]; around the shoreline of East Africa's Lake Victoria [19] [42]. In contrast, Terer et al. [36] found that only a small number of farmers in a wetland (Lobi swamp) in Kenya used papyrus as cooking fuel, but rather used firewood and charcoal, while Morrison et al. [19] point out that in East African communities papyrus rhizomes are uprooted for cooking fuel when there is a lack of alternatives. However, being of low density, large volumes of papyrus are required to produce sufficient heat for cooking [26]. Furthermore, users complain excessive amounts of smoke and ash when burning papyrus [43] [44]. On the other hand, papyrus plant material has been shown to have significant potential as a domestic fuel in the form of briquettes [19] [44] [45], dense enough to offer efficient bioenergy [7].

In the past, several efforts to implement production and use of papyrus briquettes have taken place. Jones [45] described trials to compress the papyrus into briquettes. A pilot factory was established near Kigali, Rwanda, in the early 1980s, but the project did not succeed due to insufficient funding and failure to create a product acceptable to end-users. Recent innovations in the small-scale production of papyrus briquettes developed by the "Fuel from the Field" (FftF) project at Massachusetts Institute of Technology (MIT) have been described by Morrison et al. [44]. Bundles of dried culms were carbonized using a methodology developed by MIT's D-Lab [46]. The FftF process is relatively simple, requires minimal technical expertise and utilizes locally available materials. At Lake Naivasha, Kenya, the briquettes compare favorably with wood charcoal in terms of calorific value and use characteristics, with lower emissions and therefore fewer concerns regarding human health compared to direct biomass burning [44]. A further example of using FftF-technology comes from Tanzania, where a non-profit organization is producing and selling nearly 2000 tons of carbonized briquettes per year made from coconut and rice husks, maize stalks and tree clippings. The method is also well established in Haiti and Uganda. In Haiti, more than 1000 local producers have already been trained in briquette technology. Users state that they prefer briquettes to firewood and charcoal. After starting to use briquettes, farmers report less use of firewood and wood 
charcoal. The main advantages are less smoke, longer and stronger heat, clean burning, savings on fuel expenditures and health improvements (less coughing). However, farmers require more training in briquetting and marketing support to increase production [47].

In the search for new sources of biomass for biofuel production, papyrus wetlands have been largely overlooked [7] [19] [48] [49]. There have been a small number of investigations on how papyrus wetlands can be harnessed for the benefits of local communities [35] [43] [50]. Morrison et al. [44] demonstrate a first step towards increasing the utilization of papyrus as an alternative bioenergy source possibly able to reduce pressure on forest ecosystems that currently offer the primary source of energy in SSA [7] [11]. However, in order to promote papyrus briquettes, research is needed assessing the impact of harvesting on wetland ecosystems [7] [19] [37] [46]. Furthermore, the economic viability of papyrus briquette production should be assessed, taking into account production technologies, capital costs and market linkages [11] [44] [51].

The contribution of this paper is to quantify the economy-wide impacts of introducing a small-scale papyrus briquetting business in a rural village in Zambia. Two research questions are raised: 1) Does papyrus harvesting and processing improve local livelihoods? 2) Does papyrus harvesting and processing has the potential to reduce the pressure on local forest resources?

Model-based quantitative evaluations can support wetland management through evaluating alternative management options for communities [52]. We use a Computable General Equilibrium (CGE) model to analyze the impacts of a new technology for different household groups in a village economy and capture linkages to other sector. This approach overcomes shortcomings of other methodologies due to its ability to cover comprehensive data systems, economic linkages to other sectors and actors as well as its predictive capacities [53] [54]. A CGE framework is appropriate to cover economy-wide linkages and to carry out ex-ante simulations [55]. Furthermore, the method is favorable because of its ability to produce disaggregated results at the microeconomic level within a consistent macroeconomic framework [56]. This approach has successfully been applied to food security, poverty, agriculture and also fishery [57] [58] [59] [60]. As far as we know, this study is the first that assesses the impact of papyrus briquettes on rural livelihoods and forest resources by using a CGE framework with simulations at the village level in SSA.

The remainder of this paper is structured as follows: Section 2 describes the study area and data collection. Section 3 explains the model as well as the baseline and bioenergy simulations. Simulation results are presented and discussed in Section 4 followed by the summary and conclusion in Section 5 .

\section{Study Area and Data}

The case study area is Mantapala, which is located in Zambia's Nchelenge District (Figure 1). Nchelenge is centered in northern Luapula Province at Lake 


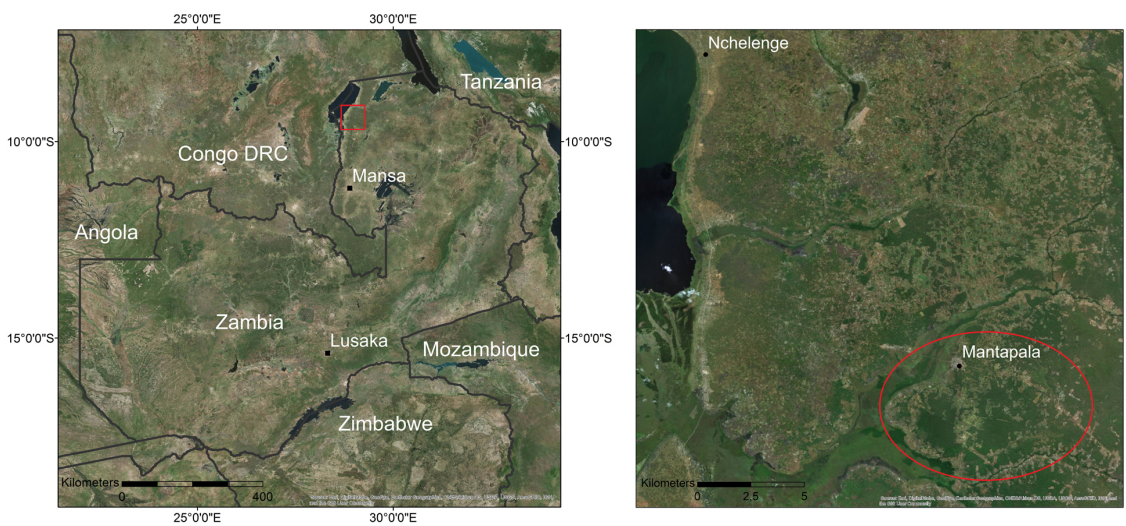

Figure 1. Mantapala in the Luapula Province, Zambia. Source: Own figure using Geographic Information System (GIS) software.

Mweru, which marks the boundary to the Democratic Republic of Congo. It is about $1100 \mathrm{~km}$ north of the capital Lusaka and $250 \mathrm{~km}$ north of the provincial capital Mansa. The lack of infrastructure (roads, financial services, trade, electricity, etc.) poses the main difficulty in the district. The area is located at an altitude of approximately $807 \mathrm{~m}$ above sea level and has a tropical climate with three seasons: winter (May-August), dry (September-October) and rainy season (November-April). Average monthly temperature does not vary greatly throughout the year, with an average of about $24^{\circ} \mathrm{C}$, but daily fluctuations can be large with lows of $11^{\circ} \mathrm{C}$ in the winter and highs of $34^{\circ} \mathrm{C}$ in the hot season. Rainfall follows a seasonal pattern, with a peak of $2700 \mathrm{~mm}$ in the rainy months and close to $0 \mathrm{~mm}$ during the dry months [61] [62].

Mantapala lies about $20 \mathrm{~km}$ east of Nchelenge town, accessible by a gravel road. It is located in the inland forest area with a hardly developed inner road network. The area covers about $130 \mathrm{~km}^{2}$ (around 3\% of the district) and hosts approximately 500 households of which the majority live in traditional huts with no electricity connection. Mantapala comprises 15 villages with a size of about 10 to 150 households per village. Poverty (less than 1.25 US\$ per capita per day) is particularly severe in the area. Luapula is one of the poorest provinces in the country. Around 8 out of 10 people from the region are considered poor and malnutrition is a serious problem. The province has the highest proportion of underweight children $(<5$ years) in the country. In addition, more than half of the population in the province has not completed primary school and nearly $10 \%$ has no education at all [63] [64] [65]. Agriculture (crop and livestock farming) and forest resources mainly determine the community's livelihoods, with marginal fishing activities in a nearby river and some streams. The majority of rural households in Mantapala grow cassava and maize next to some groundnuts, beans, sweet potato, rice and millet. Besides, many households keep small livestock (chicken, ducks, goats and pigs), whereas off-farm activities play a minor role in that region.

The forest area is characterized by productive Wet Miombo Woodland, which accounts for more than $30 \%$ in Luapula. However, most of the total area is de- 
graded, marked by high deforestation of the Miombo Woodland and related forest and grassland vegetation types [66]. The extraction of wood for energy production and shifting cultivation (land clearing for agriculture) are mainly responsible for this [67] [68] [69] [70]. Around 85\% of rural households are involved in firewood collection and over $40 \%$ in charcoal production, which is both one of the highest national estimates [64]. In Luapula, more than $90 \%$ of households are not connected to electricity [63]. Accordingly, almost all of the energy for domestic use is obtained from firewood and charcoal [63] [70] [71]. These sources are very important for many rural livelihoods, as they are needed for subsistence, but also used to generate cash income [64]. As a result of continued high annual deforestation rates (2.5\% per annum) [70], forest areas in Luapula are heavily overexploited [71], which is likely to result in other environmental impacts such as soil erosion, climate change and reduced natural habitats and rain cycles [65]. These effects may have long-term negative impacts on the livelihoods of the local population.

The Forestry Department, which falls under the Ministry of Lands, Natural Resources and Environmental Protection (MLNREP), manages the national forestry area $\left(\sim 100 \mathrm{~km}^{2}\right)$ in Mantapala and gives permits and licenses for various forest resource uses. The forest sector is regulated by the Forest Act No. 4 of 2015 and the National Forestry Policy of 2014. It is supposed to be co-managed by the Forestry Department and local key stakeholders (traditional leaders, local communities, groups/initiatives/committees) to structure forestry management plans. However, the MLNREP has not been effective in managing the forests in Zambia resulting in unsustainable exploitation of forest resources [72]. Traditional land $\left(\sim 30 \mathrm{~km}^{2}\right)$ in Mantapala is managed by the village head. Land-use permissions are given by the head while the collection of firewood and poles is unrestricted. However, the local community acts as forest overseers, i.e. illegal exploitation of forests can be communicated to the authorities at district level.

Mantapala has 3 streams that are connected or end in the Mantapala River and flow through the area towards Lake Mweru. The river and streams are available all year round (or only partially dry out at the end of the dry season). Wetlands stretch along the river and streams and are estimated at about 150 hectares. Parts of the area are well populated with papyrus and reeds, which is approximately an area of 10 to 30 hectare. Currently, wetlands in the Mantapala area are mainly used for fishing, agriculture and as a source of timber. A wetland management is missing and papyrus is only considered for housing (fencing, roofing). There is a lack of knowledge about the use of papyrus as biofuel.

Focus of the data collection was the main village (Nsemiwe/Piyala) of Mantapala, which comprises about 150 households. Primary data from the village was collected during a three-week period in September 2015. The objective was to obtain extensive descriptive information to enable the construction of a Social Accounting Matrix (SAM) for the village. The CGE parameters and variables are calibrated to a stylized format of the SAM (Appendix A). For data collection a 
household list was obtained by the head of the village. A total of 105 households (643 residents), which represent around 70\% of total households of the village, were randomly sampled. The survey covered a broad range of household's socio-demographics, networks, socio-economic activities, income sources, time allocation, consumption and expenditure, use of fish and forest resources as well as livestock and crop management. For all transactions, the performing household as well as the origin and the destination of goods produced and traded were recorded. The bioenergy module contains secondary data for the production of papyrus briquettes in the case study region. Specified parameters used for calibrating the module are shown in Appendix B.

\section{Methodology}

\subsection{Overview of the Village CGE Model}

We develop a CGE model and apply it to the economy of Mantapala village. The CGE is based on Lofgren et al. [73]. The model covers all transactions within the economy for a single year and incorporates a disaggregation of activities, commodities, factors, institutions and capital accounts. It is comprised of a comprehensive system of simultaneously linear and nonlinear equations. For production and consumption, the behaviour of actors is captured by the maximization of profits and utility, respectively. The equations also include a set of real-live constraints that have to be satisfied. These cover conditions of factor and commodity markets as well as macroeconomic balances required by economic theory.

The village CGE is formulated as a Mixed Complementarity Problem (MCP). The term MCP reflects central features of the mathematical format: "mixed" indicates that the formulation includes a mixture of equalities and inequalities; "complementarity" refers to complementary slackness between system variables and system conditions [74]. The key modelling power of complementarity is that it chooses which inequality to satisfy as equality [75]. The MCP approach accommodates the explicit treatment of activity analysis; it analyzes regime shifts and the switch between alternative activities [76]. Regime shifts denote structural changes from one system state to another, induced for example through interventions [77]. In this class of models, there is no objective function and a unique solution exists [78]. The model is programmed in the General Algebraic Modeling System (GAMS). ${ }^{1}$ In the following, we describe the main features of the village CGE model with emphasis on selected aspects. Figure 2 illustrates model features graphically.

\subsubsection{Production}

Each producer is assumed to maximize profits, defined as the difference between revenue earned and the cost of factors and intermediate inputs. The revenue is

${ }^{1}$ GAMS is designed for the construction and solution of large and complex mathematical programming models. It enables solving of various kinds of economic models including linear and non-linear optimization as well as equilibrium modelling [79]. 


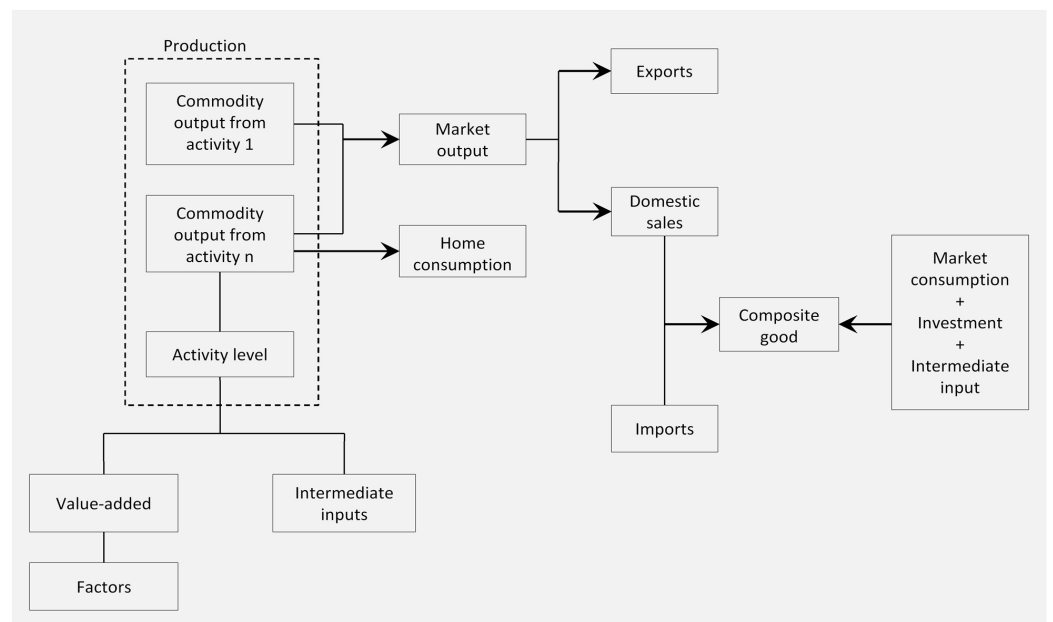

Figure 2. Structure of the village CGE model. Source: Own figure based on Lofgren et al. [73].

expended factor payments (value added) and intermediate inputs. Commodity output is defined by activity levels; hence, activities produce commodities. As part of its profit-maximizing decision, each activity uses a set of factors up to the point where the marginal revenue product of each factor is equal to the marginal cost of the factor (endogenous factor price). Production quantities are allocated to market output and households home consumption.

\subsubsection{Institutions}

Households are the main actors in the village CGE. They receive income from the factors of production, transfers from other institutions (households, government) and remittances. Income is then used for consumption, savings, inter-institutional transfers and sending remittances. Household consumption covers marketed commodities and home produced commodities. It is allocated according to a Constant Elasticity of Substitution (CES) demand function, derived from the maximization of a 2-stage additive utility function [60] [80].

Equation (1) shows the specified utility function of households. It includes a subsistence level of consumption $C_{\text {subsistence }}$ and an upper bound on family labor availability $T_{\max }$ :

$$
\begin{aligned}
& \operatorname{Max} U(C, T)=\left(C-C_{\text {subsistence }}\right)^{\alpha}+v^{*}\left(T_{\max }-T\right)^{\beta} \\
& \alpha, \beta \in(0,1), v>0
\end{aligned}
$$

The difference between maximum family labor $T_{\max }$ and actual labor $T$ represents leisure; the difference between attained household consumption $C$ and minimum required consumption $C_{\text {subsistence }}$ defines the surplus consumption of the farm household. The parameters $\alpha$ and $\beta$ determine the perceived wealth state of households as a function of consumption and leisure. A low value of parameter $\alpha$ means a relative low valuation of surplus consumption. Such value of $\alpha$ is assigned to households that tend to depend on agriculture and are close to the subsistence condition (subsistence effect). In contrast, assigning a high value 
to $\alpha$ mimics a more materialistic oriented household (farm firm effect). The parameter $v$ represents a technical coefficient of the utility function, which may be set to represent different functional forms [80].

In accordance with economic theory, the utility function yields positive and declining marginal utility of total consumption $C$ and increasing marginal disutility of labor time $T$. The expression $(1-\alpha)$ is the elasticity of the marginal utility with respect to surplus consumption $\left(C-C_{\text {subsistence }}\right)$. Total differentiation yields the shadow wage $Z$, which represents the marginal rate of substitution between consumption and labor (Equation (2)):

$$
Z=-\frac{U_{T}}{U_{C}}=\frac{\nu^{*} \beta *\left(C-C_{\text {subsistence }}\right)^{1-\alpha}}{\alpha^{*}\left(T_{\max }-T\right)^{1-\beta}}
$$

The shadow wage becomes very low when the realized consumption level approaches the minimum subsistence level and very high when leisure approaches zero. We specify subsistence consumption using a minimum bundle of goods that has to be satisfied. ${ }^{2}$ Implementing specific functional forms has important implications for model outcomes. In the two product case (here aggregate consumption and leisure), the utility function applied is flexible; the elasticity of $Z$ with respect to $\alpha$ and $\beta$ depends on the actually realized levels of surplus consumption and leisure. This means, different household groups may respond differently to a policy change.

\subsubsection{Commodities and Trade}

For market output, any commodity is defined as a Leontief aggregate of the different activities producing the commodity. The optimal quantity of the commodity from each activity is inversely related to the activity specific price. A decline in the price of one activity relative to others would shift demand in its favor by eliminating/decreasing the demand to other higher-price sources. Trade inside the rural economy is performed between households within the case study village and captured by domestic sales. Trade outside the rural economy (imports and exports) mainly takes place with surrounding villages. Hence, the model is constructed as a small open economy. We employ linear functions for imports, exports and domestic sales. The allocation of market output is addressed to domestic sales and exports; under the assumption of perfect transformability between these two destinations. Perfect substitutability between imports and domestic sales is captured by a linear aggregation function calculating the composite good. The assumptions of perfect transformability and perfect substitutability give the model the flexibility for (totally) shifting between trade flows depending on relative prices of imports, exports and domestic products. ${ }^{3}$

\footnotetext{
${ }^{2}$ The consumer bundle of the case study region mainly comprises maize, cassava, tomato, nuts, rice, beans, pumpkin, mango, millet, fish, firewood, charcoal, livestock products, bread, flour, sorghum, clothing, education, transport and mobile phone expenses.

${ }^{3}$ In contrast, the Armington [81] assumption is based on imperfect transformability and substitutability. He used constant elasticity of substitution for imports and constant elasticity of transformation for exports, which mathematically avoid a total elimination of unproductive trade flows. Hence, he did not allow any regime shifts.
} 


\subsubsection{Macroeconomic Balances}

The factor demand is flexible while the supply is fixed. Economy-wide factor price variables are free to vary (endogenous), and factors are mobile between the demanding activities. The real exchange rate is fixed, since the village is not connected to a foreign country, and foreign expenses are flexible and serve the role of equilibrating variable to the current-account balance. A macro-economic closure is used to incorporate a "balanced" savings-investment handling [73].

\subsection{Baseline Simulation}

People living in Mantapala village heavily depend on forest resources. Firewood collection and charcoal production contributes almost half (48\%) to the village GDP. The total GDP is around 600,000 ZMK (930 ZMK per capita), around one fourth of the provincial average [82]. Crop production contributes $41 \%$, fishing $7 \%$, livestock farming $3 \%$ and trade $0.3 \%$ to the village GDP. The share of imports and exports in GDP (trade openness ratio) is $34 \%$ with only some commodities being traded. The village imports hardly any agricultural and wood products and is therefore largely self-sufficient in agriculture and energy supply, while heavily depends on purchases of non-food products (clothing, education, transport, mobile phone expenses). Only $3 \%$ of total gross output is exported, mainly cassava and maize, which means that most of the production remains within the village.

We distinguish between two household groups in the model, namely male and female headed households. Table 1 gives an overview of the households' socio-economic characteristics. Overall, the households' socio-demographics are very similar, but income varies. The income of a female headed household is above that of the male. This may be due to the fact that women spend more time working and therefore gain more income (yields) from subsistence production and firewood collection. Nevertheless, income of all households is below the poverty threshold of 1.25 US\$ per capita and day [63]..$^{5}$

Households have diversified livelihood strategies, mainly based on subsistence agriculture and forest resource extraction. For the most part, farmers cultivate cassava and maize on 1 - 3 hectares of land, and plots are usually a few kilometers away from home. Shifting cultivation is a common practice. The per capita consumption of firewood in rural Zambia is estimated at $1025 \mathrm{~kg}$ [70], which is slightly above the Mantapala average ( $818 \mathrm{~kg}$ firewood per capita). Forest resources are almost entirely used for subsistence needs in the study region.

The extraction of wood for energy production is one reason for deforestation in rural Zambia [66] [68] [69] [71] with continued high annual deforestation

${ }^{4}$ This is ensured by simultaneous adjustments in three (endogenous) components of absorption: household consumption, investment quantity and government consumption. Under other investment-driven closures (value of savings adjusts), the quantities of investment and government consumption are both fixed, only household consumption is flexible [73].

${ }^{5} 1$ US\$= 10 ZMK (March 2018). 
Table 1. Household groups' characteristics. Source: Own calculation.

\begin{tabular}{ccc}
\hline Household groups & $\begin{array}{c}\text { Male headed } \\
\text { household }\end{array}$ & $\begin{array}{c}\text { Female headed } \\
\text { household }\end{array}$ \\
\hline Number of households & 83 & 22 \\
Household members (number) & 6.1 & 6.1 \\
Age of household head (years) & 43.0 & 39.0 \\
Household members < 16 (number) & 3.3 & 3.5 \\
Education of household head (grade) & 6.6 & 3.9 \\
Education of household members (grade) & 4.3 & 4.3 \\
Farmland (hectare) & 1.7 & 2.6 \\
\% agriculture & 4808 & 9095 \\
\% fish resources & 39.8 & 41.8 \\
\% livestock & 7.3 & 7.4 \\
\% forest resources & 3.3 & 1.7 \\
\% trade & 46.6 & 47.8 \\
\% monetary transfers and remittances & 0.3 & 0.4 \\
Firewood consumption (kg) & 2.6 & 0.9 \\
Charcoal consumption (kg) & 862 & 9119 \\
\hline ZMK per household and year) & 770 & 1677 \\
\hline
\end{tabular}

rates of $2.5 \%$ in Luapula Province [70]. Forest resource utilization is therefore defined as unsustainable [71] [72]. Figure 3 shows the decline in forest area in the Mantapala village community over time covering the year 1990, 2000, 2009 and 2016. Baseline model results show that almost 20 hectares of forest are cut each year for bioenergy production. Currently, wetlands are only important for some households in Mantapala as they cultivate their fields close to them. Wetland products such as papyrus play no role for energy supply.

\subsection{Papyrus Harvesting and Processing Simulation}

To evaluate the impact of papyrus briquetting on the village economy, a bioenergy module was constructed and implemented within the existing CGE modelling framework. Generally, there are two alternatives for linking new modules to a model: 1) separate models can be combined via interfaces (e.g. top-down, bottom up), or 2) a model can be completely integrated through defining additional activities and constraints leaving the initial model framework unchanged [83] [84] [85] [86]. Using the latter approach, we construct a bioenergy module and integrate it into the village CGE model.

According to the FftF-method developed by MIT's D-Lab [46] we defined a new production system of papyrus briquetting. Novel carbonized briquettes can be produced from papyrus culms using locally manufactured tools. The use of papyrus as a biofuel for cooking and heating depends on the premise of 

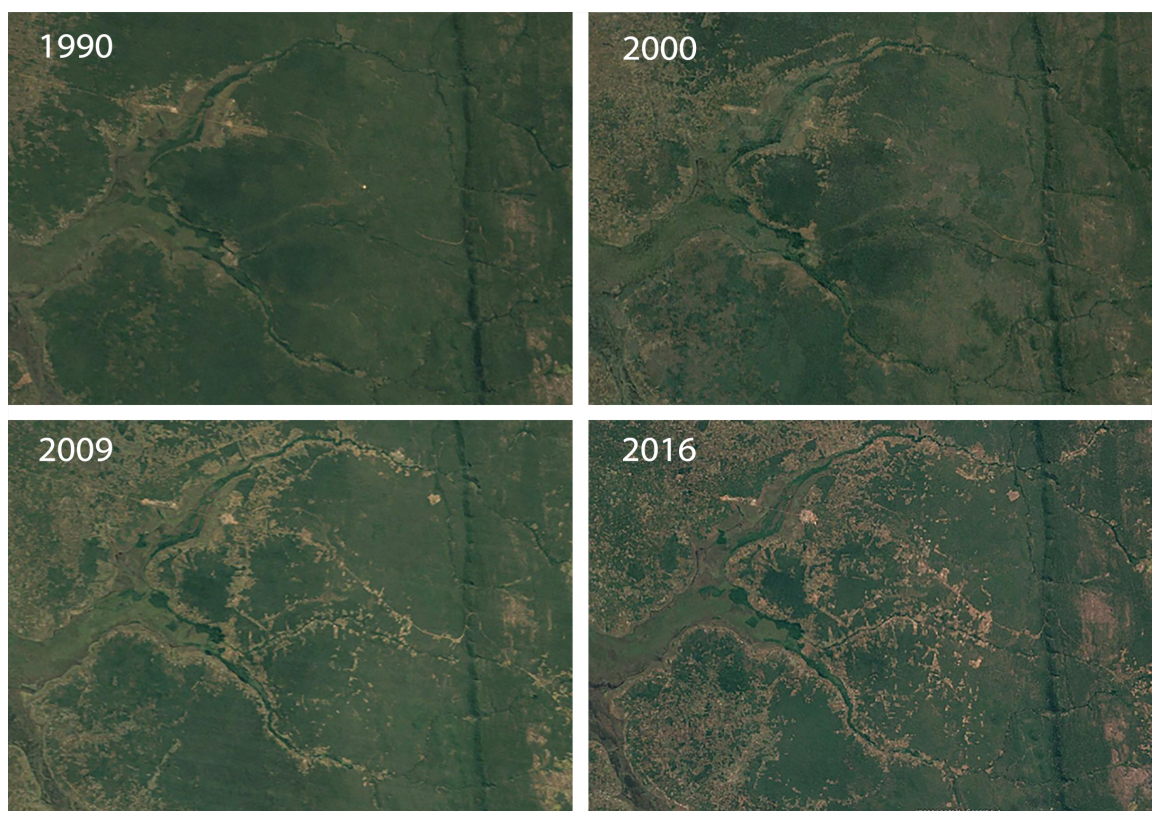

Figure 3. Decreasing woodland in Mantapala over time. Source: Own figure using GIS software.

converting it to a suitable combustible form. Bundles of dried culms are carbonized whilst using a converted 200-liter oil drum as a carbonizing kiln. A large hole in the top of the drum and a number of smaller holes in the base allow for airflow during the initial combustion of the biomass. The majority of the volatile organic compounds in the papyrus burn off during the initial stages of the combustion. Once the papyrus reaches carbonization temperature $\left(\sim 450^{\circ} \mathrm{C}\right)$, the kiln is sealed to create an anaerobic environment to produce charcoal. The cooled carbonized papyrus is crushed by hand and mixed with a $5 \%-10 \%$ by weight binder of cassava flour in heated water to create a porridge-like consistency. Afterwards, it is formed into cuboid briquettes using a simple press manufactured locally from scrap materials [7] [44].

For the activity explained above, intermediate inputs and factors are required (Figure 4), and production is modelled according to a Leontief production function. In the first stage, papyrus is harvested using the wetland and labor as production factors. Papyrus vegetation can be harvested by hand and needs to be air-dried before utilization [19] [45]. The second stage of production is the production of papyrus briquettes. Papyrus is processed into charcoal briquettes, requiring dried papyrus, cassava flour and water freely accessible through the river and streams as intermediate inputs and labor as a production factor. The equivalent mass of $1 \mathrm{~m}^{2}$ of cut and dried culm units is placed in the oil drum of carbonizing kiln. After carbonization and crushing, a binding material of $10 \%$ of the weight of carbonized papyrus plus 3 liters of cold water are added. The viscous mass is formed in briquettes by a small metal press [44]. The oil drum converts papyrus into carbonized material within a couple of hours, and the charcoal press presses carbonized material into briquettes at speeds up to $10-15$ 


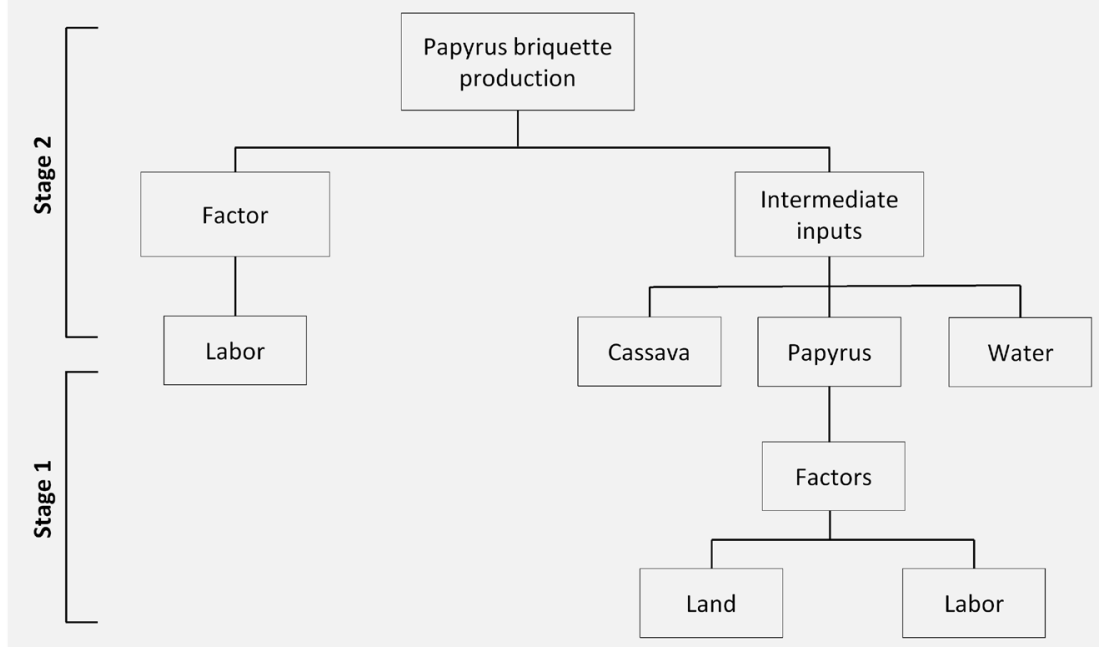

Figure 4. Bioenergy module. Source: Own figure.

briquettes per minute [46]. Finally, the briquettes have to dry. Generated yields, i.e. papyrus briquettes, can be used for households' home use and sales in the simulation.

The FftF-process is simple, requires minimal technical expertise, and locally available materials can be purchased for around 30 US\$ [44] [46]. The metal press for the production of cuboid briquettes can easily be manufactured locally and rarely has to be replaced if manufactured correctly. It can be operated by a single individual [44], whereas the work in connection with the carbonization process at the oil drum requires 1 - 2 individuals [46]. According to MIT's D-Lab [46] a farmer can produce enough briquettes to pay for the equipment and start making a profit in less than a month. Microcredit institutions may provide loans to help entrepreneurs that cannot afford the initial investment, or farmers may form charcoal cooperatives. Hence, the bioenergy module considers an operating system. In our simulation, the initial investment costs are covered by donor support; alternatively, households' private savings, a loan or cooperatives may be accessible for investments.

In the simulation, investments in papyrus briquetting are equivalent to $2 \%$ of the village GDP. ${ }^{6}$ This corresponds to the implementation of 4 production systems (one oil drum and one metal press per system); the investment represents a realistic small-scale business in the region. The model determines to what extent the new technology will replace conventional energy production and thus conserves forest resources.

\section{Results and Discussion}

The simulation shows that rural households could use papyrus as an alternative

${ }^{6}$ Marginal interventions cannot be estimated reliably within the modelling system. Within the scope of the module calibration, the factor supply of the economy is increased, however, in the simulation it is set back to the original value, since this is fixed. The model then decides whether the technology is implemented. 
biofuel. The possibility to produce papyrus briquettes leads to extensive labor reallocations in the village economy. Households shift from firewood extraction and charcoal production to papyrus harvesting and processing, which increases the income and utility of all household groups (see Table 2). The modelled integration of 4 papyrus briquette production systems increases the overall GDP by around 2\% compared to the baseline. The simulation shows that the income of male headed households' changes slightly more than that of female headed ones. Members of this group use their labor time less effectively and thus benefit relatively more from switching to papyrus harvesting and processing. Nevertheless, their income remains below that of female headed households.

The transformed energy production is also reflected in modified opportunity costs (shadow prices) of labor. The opportunity costs of labor increase for all households, but to varying degrees, which reflects their individual gain attributable to the intervention. Although shadow prices are on average about $2 \%$ higher than the baseline, they are still significantly below the poverty threshold of 1.25 US\$ per capita per day. This is in line with the literature, exposing that poverty is particularly severe in the region [63] [64] [65]. Growing deforestation causes households to spend large parts of their time on collecting firewood and producing charcoal. The increased shadow price after switching to papyrus processing indicates the increased value of a working day in the study region. The opportunity costs derived by the economy-wide CGE analysis can be interpreted as the incentive price for households to stop deforestation.

Female headed households are mainly responsible for firewood harvesting in the region. This is explained by the fact that this group uses more firewood for home activities. Furthermore, higher food consumption of female headed households may be associated with a higher energy demand, primarily obtained from wood. Accordingly, female headed households should be in the focus of interventions that address alternative energy supplies. The gender specific shadow price for labor is 3.4 ZMK for male and 10.9 ZMK per day for female headed households respectively. The higher shadow price for women signals that they

Table 2. Papyrus harvesting and processing simulation results. Source: Own calculations.

\begin{tabular}{ccc} 
Household groups & $\begin{array}{c}\text { Male headed } \\
\text { household }\end{array}$ & $\begin{array}{c}\text { Female headed } \\
\text { household }\end{array}$ \\
\hline Total income (\% change) & 1.5 & 0.2 \\
Utility (\% change) & 0.3 & 0.7 \\
Shadow wage (ZMK per day) & 3.4 & 10.9 \\
Consumption (\% change) & 2.2 & 3.7 \\
Leisure (\% change) & 1.6 & 41 \\
Firewood consumption (decrease in $\mathrm{kg}$ ) \\
Charcoal consumption (decrease in $\mathrm{kg}$ )
\end{tabular}


generally use labor time more effectively. Calculated opportunity costs correspond quite well with the daily minimum wage for Zambian domestic workers, which is between $2.7 \mathrm{ZMK}$ to $7.5 \mathrm{ZMK}$ per working day [87]. Furthermore, group-specific opportunity costs provide information about compensation payments that are necessary to make a certain intervention acceptable for differently affected households.

Compared to firewood and charcoal, an equivalent unit of energy obtained from papyrus requires less work in terms of time. As a result of the computer-generated substitution processes, more household labor is available for additional production activities. Compared to the baseline, this effect leads to consumption increases by $2.2 \%$ for male and $4.7 \%$ for female headed households. Assumed by the specified non-homothetic Angelsen utility function, households utility derives from the bundle of consumption of a composed good and leisure, whose relative shares change disproportionally as a function of total utility. In the discussed alternative energy scenario, increasing utility, caused by the shift from firewood collection and processing to papyrus harvesting and processing, leads to the reallocation of households' total available time; working time decreases and leisure time increases respectively (by 1.6\% for male and 3.7\% for female headed households). Altogether, the intervention leads to improved local livelihoods through direct benefits from income and utility growth.

Model results show that the novel low-tech briquette production system, relying on locally available tools and inputs, is a feasible activity within the village economy. The break-even point of a briquette production system, consisting of a locally available oil drum and a metal press valued at 30 US\$, would be reached after approximately 3 months for a male or 1 month for a female headed household. Morrison et al. [44] found that papyrus briquettes compare favorably with wood charcoal in terms of calorific value and use characteristics. Table 2 indicates that households' consumption of firewood and charcoal decreases. The 4 specified briquette production units are realized by the CGE model to generate the missing amount of energy equivalents. In the model solution, the new technology only provides a small part of the total energy needed in the village (1.6\%). This is due to capacity limitations predefined in the scenario (4 briquetting systems were introduced as an investment intervention). The revealed feasibility of the novel technology within the virtual village economy, however, leaves room for testing such a novel energy system in a real-world setting.

Nevertheless, though being more labor efficient, briquetting requires knowledge transfer and training, which makes the implementation in remote wetland areas difficult. Studies from Lake Victoria, Kenya, found that wetland activities such as papyrus collection are labor-intensive [37], but require few skills and are highly imitable [88]. Thenya and Ngecu [37] state that this activity is more often undertaken by men, whereas Holt and Littlewood [88] point out that it is rather carried out by widowed women groups and is considered as unpopular (dirty) work for the marginalized people. However, the introduction of new processing 
technologies and innovative products such as papyrus briquettes could improve the negative image and create an alternative livelihood.

In SSA, wetlands are important to support the nature-based tourism industry. Local wildlife provides an indirect source of income for rural communities [37] [89]. It has to be assessed if papyrus harvesting complements incomes or represents a competing use of the wetland. Principally, papyrus wetlands can reduce poverty through higher income generation [48]. However, limiting factors for papyrus harvesting and processing, not presented in the model, are waterborne diseases (malaria, cholera, diarrhea), bites from snakes, poor transport infrastructure and accidents caused by processing [11] [43]. In addition, Morrison et al. [19] emphasize that many people at Lake Naivasha, Kenya, lack the knowledge of what papyrus can be used for. The lack of a consumptive use value for papyrus limits people's awareness of its broader economic, social and environmental benefits.

Regarding the nexus of energy needs and food security, the use of cassava binder for the production of papyrus briquettes is a critical point. Malnutrition is already very serious in the region [63] [65], and the use of food for fuel is heavily debated. The amount of cassava flour used in the 4 implemented production systems is approximately $340 \mathrm{~kg}$ per year (or $930 \mathrm{~g}$ per day). It remains questionable whether households are really willing to use cassava for bioenergy production when food shortages are a daily challenge [44].

Considering environmental issues, the shift of households away from firewood and charcoal producing activities towards papyrus harvesting and processing might decrease deforestation. In our simulation, the use of wood as a fuel source declines by approximately $3600 \mathrm{~kg}$, which would conserve forest resources (see Table 3). Based on biomass calculations for Miombo Woodlands in Zambia [90], the calculated reduction in forest degradation corresponds to an area of $0.31 \mathrm{ha}\left(3100 \mathrm{~m}^{2}\right)$. Assuming further that 1 hectare Miombo Woodland comprises 576 trees [68], nearly 180 trees per year are conserved due to the new technology available. Yet to produce the corresponding unit of energy equivalents, the wetland ecosystem would be put under pressure. In terms of land use, however, this is less than the comparative area of forest. The realized 4 production systems produce nearly $3400 \mathrm{~kg}$ of briquettes, which need about 15,000 kg of papyrus, assuming that $1 \mathrm{~kg}$ of briquettes corresponds to $4.59 \mathrm{~kg}$ papyrus [44]. Assuming further a mean value of $5.33 \mathrm{~kg}$ per $\mathrm{m}^{2}$ aerial dry weight wetland biomass of papyrus [44], this corresponds to nearly 0.29 hectare. A conversion factor of 1.05 is calculated, indicating that 1.05 hectare of forest area can be substituted by 1 hectare of wetland to produce an equivalent unit of energy.

Table 3. Forest and wetland use. Source: Own calculations.

\begin{tabular}{ccc}
\hline Resource & Kilogram & Hectare \\
\hline Forest use (decline) & 3600 & 0.31 \\
Wetland use (increase) & $3400(15,000)$ & 0.29 \\
\hline
\end{tabular}


The substitution is accompanied by price differences for forest and wetland resources (see Table 4). The model shows that the shadow price of 1 kilogram of firewood and charcoal has a value of $0.3 \mathrm{ZMK}$ and $1.1 \mathrm{ZMK}$, respectively, whereas papyrus has a shadow price of $0.6 \mathrm{ZMK}$ and briquettes $3.7 \mathrm{ZMK}$ per $\mathrm{kg}$. The shadow prices calculated are comparable to the market prices of these goods. The model therefore predicts possible price developments by papyrus briquetting, which could be considered in the context of a possible practical intervention.

Being fast-growing and locally abundant in wetlands of central, eastern and southern Africa, the model shows that papyrus would be a suitable alternative source of biomass for fuel when processed into briquettes. It has the potential to reduce pressure on regional forests exploited for fuelwood and charcoal production, which is in line with Morrison et al. [44]. Due to unsustainable forest use claimed by Syampungani et al. [71] and the Report of the Auditor General on Sustainable Forest Management [72] as well as high deforestation rates [70], which endanger local livelihoods, a change in the current situation is urgently needed. Based on the results shown, it can be stated that papyrus briquetting has the potential to reduce the pressure on local forest resources.

The substitution of forest resources by papyrus for bioenergy production not only has a resource-conserving effect, but may also improve human health. The combustion of carbonized briquettes produces lower emissions affecting human health [44]. Combustion of biomass in the form of wood and charcoal is estimated to lead to the annual premature death of 400,000 individuals in SSA [91].

While papyrus plant material has been shown to have significant potential as a domestic fuel [44] [45] [46], sustainable harvesting regimes are required to maintain the biofuel supply chain in the long term [7]. Papyrus wetlands generally have no seasonality [14]. The values of standing biomass are relatively stable with individual culms being present in multiple age classes throughout the year [8] [12]. The effect of harvesting frequency on sustainable yield of papyrus has been investigated in a small number of trials, suggesting a duration between 3.5 and 24 months for a sustainable harvest [8] [12] [38] [92]. Terer et al. [35] investigated the effects of repeatedly harvesting papyrus at 6 and 12 monthly intervals at Lake Naivasha, Kenya, and showed that a 12 monthly harvesting regime offers enough time between harvests for a full cycle of growth from young stems to senescence. A study by Morrison et al. [44] shows that it is possible to selectively harvest up to $90 \%$ of the biomass, leaving young culms intact and thus maintain

Table 4. Shadow prices for forest and wetland resources. Source: Own calculations.

\begin{tabular}{ccc}
\hline Price per kg & \% Change to baseline & ZMK \\
\hline Firewood & 14.2 & 0.3 \\
Charcoal & 2.5 & 1.1 \\
Raw papyrus & 14.3 & 0.6 \\
Papyrus briquettes & 10.7 & 3.7
\end{tabular}


the regenerative capacity of the wetland for repeated harvesting. Cleared papyrus regenerates after 9 - 12 months of uninterrupted growth [43], and rhizomes should generally not be harvested [27]. The drier periods allow access for papyrus harvesting. The rainy season, when the wetlands are flooded and therefore access to papyrus is difficult and the corresponding risks are higher [43], can be used as a recover period of the papyrus vegetation [11]. However, there is still a need for research into a sustainable harvest of papyrus, taking into account the entire wetland system.

\section{Summary and Conclusion}

Research has not yet been carried out extensively in order to promote papyrus briquettes and assess the economic viability of briquette production. There have been a small number of investigations on how papyrus wetlands can be harnessed for the benefits of local communities. Accordingly, our contribution to science is the construction of a village CGE to investigate the impact of papyrus harvesting and processing on rural livelihoods and forest resources in a case study region in Zambia. This approach can also be adopted to other regions which are similarly affected by energy supply.

This paper addressed two research questions: 1) Does papyrus harvesting and processing improve local livelihoods? 2) Does papyrus harvesting and processing has the potential to reduce the pressure on local forest resources? The results show that papyrus briquetting would be a possible alternative biofuel and contributes to income and utility improvements of households. Calculated opportunity costs provide information about compensation payments necessary to make interventions acceptable and successful. It is found that the production of bioenergy from papyrus improves the local livelihoods. In addition, households tend to give up their forest harvesting and charcoal production activity in order to switch to papyrus uses. Forest land is conserved and replaced by a smaller area of wetland for bioenergy generation. Papyrus briquettes thus substitute energy supplies from firewood and charcoal and have the potential to reduce pressure on local forest resources in the region.

Further research is needed to assess the long-term impacts of papyrus briquetting in the case study region. The specified village CGE model is static, taking a one-year perspective. It cannot predict the dynamics of a long-term development path and its feed-back loops. One inherent limitation of the method is that real agents' behavior may diverge from optimality (profit and utility maximization) because they may not behave rationally and independently [93]; it is possible that they respond to other agents' actions more easily [94]. This requires the development of dynamic modelling tools such as agent-based models. For further investigations it should be taken into account that the model shows effects related to a $2 \%$ GDP intervention, which is equivalent to 4 papyrus briquette production systems. So far, only a few studies have assessed the economic viability of papyrus wetlands and the benefits for local communities, which provide 
scope for further research.

The sustainable management of wetlands should also not be neglected when using papyrus as an alternative biofuel. Although high productivity rates of papyrus have been confirmed, there are concerns about the regeneration potential [12] and the sustainable use of wetlands [35]. To enhance land management decisions and policy-making, a holistic approach must be undertaken in an interdisciplinary context where the results from the natural sciences are linked to social science research [95]. Results from this model could guide the negotiation of necessary benefit distribution schemes from papyrus briquetting and forest resource conservation, which are particularly important for the governance structure.

\section{Acknowledgements}

This article has been written in the context of the project "SASSCAL-Southern African Service Science Centre for Climate Change and Adaptive Land Management" (http://www.sasscal.org/) and "FOSEZA-Food Security in rural Zambia" (http://www.foseza.uni-hannover.de). SASSCAL is funded by the German Ministry of Education and Research (BMBF) [01LG1201H]. FOSEZA is funded by the German Ministry of Food and Agriculture (BMEL) [2813FSNU11]. First of all, the authors express thanks to the people living in Mantapala for their continuous cooperation. They also thank Beatrice Nöldeke, who supported the work in various stages.

\section{References}

[1] International Energy Agency (2010) World Energy Outlook 2010. IEA/OECD, Paris.

[2] Cerutti, P.O., Sola, P., Chenevoy, A., et al. (2015) The Socioeconomic and Environmental Impacts of Wood Energy Value Chains in Sub-Saharan Africa: A Systematic Map Protocol. Environmental Evidence, 4, 12. https://doi.org/10.1186/s13750-015-0038-3

[3] Murphy, J.T. (2001) Making the Energy Transition in Rural East Africa: Is Leapfrogging an Alternative? Technological Forecasting and Social Change, 68, 173-193. https://doi.org/10.1016/S0040-1625(99)00091-8

[4] International Energy Agency (2014) Africa Energy Outlook: A Focus on Energy Prospects in Sub-Saharan Africa. World Energy Outlook Special Report. IEA/OECD, Paris.

[5] Wessels, K.J., Colgan, M.S., Erasmus, B.F.N., et al. (2013) Unsustainable Fuelwood Extraction Form South African Savannas. Environmental Research Letters, 8, 1-10. https://doi.org/10.1088/1748-9326/8/1/014007

[6] HLPE (2017) Sustainable Forestry for Food Security and Nutrition. A Report by the High Level Panel of Experts on Food Security and Nutrition, Rome.

[7] Jones, M.B., Kansiime, F. and Saunders, M.J. (2018) The Potential Use of Papyrus (Cyperus papyrus L.) Wetlands as a Source of Biomass Energy for Sub-Saharan Africa. GCB Bioenergy, 10, 4-11. https://doi.org/10.1111/gcbb.12392

[8] Jones, M.B. and Muthuri, F. (1997) Standing Biomass and Carbon Distribution in a 
Papyrus (Cyperus papyrus L.) Swamp on Lake Naivasha, Kenya. Journal of Tropical Ecology, 13, 347-356. https://doi.org/10.1017/S0266467400010555

[9] Saunders, M.J., Jones, M.B. and Kansiime, F. (2007) Carbon and Water Cycles in Tropical Papyrus Wetlands. Wetlands Ecology and Management, 15, 489-498. https://doi.org/10.1007/s11273-007-9051-9

[10] Junk, W.J., An, S., Finlayson, C.M., Gopal, B., Kvet, J., Mitchell, S.A. and Robarts, R.D. (2013) Current State of Knowledge Regarding the World's Wetlands and Their Future under Global Climate Change: A Synthesis. Aquatic Sciences, 75, 151-167. https://doi.org/10.1007/s00027-012-0278-Z

[11] van Dam, A.A., Kipkemboi, J., Mazvimavi, D. and Irvine, K. (2014) A Synthesis of Past, Current and Future Research for Protection and Management of Papyrus (Cyperus papyrus L.) Wetlands in Africa. Wetlands Ecology and Management, 22, 99-114. https://doi.org/10.1007/s11273-013-9335-1

[12] Osumba, J.J.L., Okeyo-Owuor, J.B. and Raburu, P.O. (2010) Effect of Harvesting on Temporal Papyrus (Cyperus papyrus) Biomass Regeneration Potential among Swamps in Winam Gulf Wetlands of Lake Victoria Basin, Kenya. Wetlands Ecology and Management, 18, 333-341. https://doi.org/10.1007/s11273-010-9174-2

[13] Jones, M.B. (1982) The Productivity of Papyrus. Report to the Bilateral Aid Section of the Ministry of Foreign Affairs, Government of Ireland, 18.

[14] Mnaya, B., Asaeda, T., Kiwango, Y. and Ayubu, E. (2007) Primary Production in Papyrus (Cyperus papyrus L.) of Rubondo Island, Lake Victoria, Tanzania. Wetlands Ecology and Management, 15, 269-275. https://doi.org/10.1007/s11273-006-9027-1

[15] Perbangkhem, T. and Polprasert, O. (2010) Biomass Production of Papyrus (Cyperus papyrus) in Constructed Wetland Treating Low-Strength Domestic Water. Bioresource Technology, 101, 833-835. https://doi.org/10.1016/j.biortech.2009.08.062

[16] Millennium Ecosystem Assessment (2005) Ecosystems and Human Well-Being: Wetlandsand Water Synthesis. World Resources Institute, Washington DC.

[17] Maltby, E. and Acreman, M.C. (2011) Ecosystem Services of Wetlands: Pathfinder for a New Paradigm. Hydrological Sciences Journal, 56, 1341-1359. https://doi.org/10.1080/02626667.2011.631014

[18] Russi, D., ten Brink, P., Farmer, A., Badura, T., Coates, D., Förster, J., Kumar, R. and Davidson, N. (2013) The Economics of Ecosystems and Biodiversity for Water and Wetlands. IEEP, London.

[19] Morrison, E.H.J., Upton, C., Pacini, N., Odhiambo-K'oyooh, K. and Harper, D.M. (2013) Public Perceptions of Papyrus Community Appraisal of Wetland Ecosystem Services at Lake Naivasha, Kenya. Ecohydrology \& Hydrobiology, 13, 135-147. https://doi.org/10.1016/j.ecohyd.2013.03.008

[20] Millennium Ecosystem Assessment (2005) Ecosystems and Human Well-Being: Synthesis. Island Press, Washington DC.

[21] Maclean, I.M.D., Hassall, M., Boar, R.R. and Lake, I.R. (2006) Effects of Disturbance and Habitat Loss on Papyrus-Dwelling Passerines. Biological Conservation, 131, 349-358. https://doi.org/10.1016/j.biocon.2005.12.003

[22] Mitsch, W.J., Nahlik, A., Wolski, P., Bernal, P., Zhang, L. and Ramberg, L. (2010) Tropical Wetlands: Seasonal Hydrological Pulsing, Carbon Sequestration, and Methane Emissions. Wetlands Ecology and Management, 18, 573-586. https://doi.org/10.1007/s11273-009-9164-4

[23] Saunders, M.J., Kansiime, F. and Jones, M.B. (2012) Agricultural Encroachment: 
Implications for Carbon Sequestration in Tropical African Wetlands. Global Change Biology, 18, 1312-1321. https://doi.org/10.1111/j.1365-2486.2011.02633.x

[24] Kansiime, F., Saunders, M. and Loiselle, S. (2007) Functioning and Dynamics of Wetland Vegetation of Lake Victoria: An Overview. Wetlands Ecology and Management, 15, 443-451. https://doi.org/10.1007/s11273-007-9043-9

[25] Ryken, N., Vanmaercke, M., Wanyama, J., Isabirye, M., Vanonckelen, S., Deckers, J. and Poesen, J. (2015) Impact of Papyrus Wetland Encroachment on Spatial and Temporal Variabilities of Stream Flow and Sediment Export from Wet Tropical Catchments. Science of the Total Environment, 511, 756-766. https://doi.org/10.1016/j.scitotenv.2014.12.048

[26] Owino, A.O. and Ryan, P.G. (2007) Recent Papyrus Habitat Loss and Conservation Implications in Western Kenya. Wetlands Ecology Management, 15, 1-12. https://doi.org/10.1007/s11273-006-9001-y

[27] van Dam, A.A., Kipkemboi, J., Zaal, A.M. and Okeyo-Owuor, J.B. (2011) The Ecology of Livelihoods in East African Papyrus Wetlands (ECOLIVE). Reviews in Environmental Science and Bio/ Technology, 10, 291-300. https://doi.org/10.1007/s11157-011-9255-6

[28] Laws, B. (2011) Fifty Plants that Changed the Course of History. Allen \& Unwin, London.

[29] Gaudet, J. (2014) Papyrus, the Plant that Changed the World: From Ancient Egypt to Today's Water Wars. Pegasus Books, New York, London.

[30] Geheb, K. and Binns, T. (1997) "Fishing Farmers" of "Farming Fishermen"? The Quest for Household Income and Nutritional Security on the Kenyan Shores of Lake Victoria. African Affairs, 96, 73-93. https://doi.org/10.1093/oxfordjournals.afraf.a007822

[31] Rongoei, P.J., Kipkemboi, J., Okeyo-Owuor, J.B. and van Dam, A.A. (2013) Ecosystem Services and Drivers of Change in Nyando Floodplain Wetland, Kenya. African Journal of Environmental Science and Technology, 7, 274-291.

[32] Barakagira, A. and Kateyo, E. (2008) Impacts of Wetland Drainage on Domestic Water Supplies and People's Livelihoods in Kabale District, Uganda. Paper Presented at the 12th Biennial Conference of the International Association for the Study of Commons, University of Gloucestershire, UK.

[33] Ojoyi, M.M. (2006) Sustainable Use of Papyrus (Cyperus papyrus) at Lake Victoriawetlands in Kenya: A Case Study of Dunga and Kusa Swamps. Monetary Institute of Technology and Higher Education, Mexico.

[34] Kansiime, F. and Nalubega, M. (1999) Wastewater Treatment by a Natural Wetland: The Nakivubo Swamp, Uganda. Ph.D. Thesis, Wageningen Agricultural University, Balkema, Ratterdam.

[35] Terer, T., Triest, L. and Muthama Muasya, A. (2012) Effects of Harvesting Cyperus papyrus in Undisturbed Wetland, Lake Naivasha, Kenya. Hydrobiologia, 680, 135-148. https://doi.org/10.1007/s10750-011-0910-2

[36] Terer T., Muthama Muasya, A., Dahdouh-Guebas, F., Ndiritu, G.G. and Triest, L. (2012) Integrating Local Ecological Knowledge and Management Practices of an Isolated Semi-Arid Papyrus Swamp (Loboi, Kenya) into a Wider Conservation Framework. Journal of Environmental Management, 93, 71-84. https://doi.org/10.1016/j.jenvman.2011.08.005

[37] Thenya, T. and Ngecu, W.M. (2017) Indigenous Strategies and Dynamics of Resource Utilization in Tropical Wetland. A Case Study of Yala Swamp, Lake Victoria Basin, Kenya. International Journal of Arts and Commerce, 6, 21-39. 
[38] Muthuri, F., Jones, M. and Imbamba, S. (1989) Primary Productivity of Papyrus (Cyperus papyrus) in a Tropical Swamp, Lake Naivasha, Kenya. Biomass, 18, 1-14. https://doi.org/10.1016/0144-4565(89)90077-2

[39] Opio, A., Jones, M.B., Kansiime, F. and Otiti, T. (2014) Growth and Development of Cyperus papyrus in a Tropical Wetland. Open Journal of Ecology, 4, 113-123. https://doi.org/10.4236/oje.2014.43013

[40] Gaudet, J.J. (1998) When Papyrus Ruled; The Versatile Plant That Strengthened Pharaohs of Egypt. The Washington Post, Washington DC, H01.

[41] Cohen-Shacham, E., Dayan, T., Feitelson, E. and de Groot, R.S. (2012) Ecosystem Service Trade-Offs in Wetland Management: Drainage and Rehabilitation of the Hula, Isreal. Hydrological Sciences Journal, 56, 1582-1601. https://doi.org/10.1080/02626667.2011.631013

[42] Gickuki, J., Dahdough Guebas, F., Mugo, J., Rabuor, C.O., Triest, L. and Dehairs, F. (2001) Species Inventory and the Local Uses of the Plants and Fishes of the Lower Sondu Miriu Wetland of Lake Victoria, Kenya. Hydrobiologia, 458, 99-106. https://doi.org/10.1023/A:1013192330498

[43] Morrison, E.H.J., Upton, C., Odhhiambo-K'hyooh, K. and Harper, D.M. (2012) Managing the Natural Capital of Papyrus within Riparian Zones of Lake Victoria, Kenya. Hydrobiologia, 692, 5-17. https://doi.org/10.1007/s10750-011-0839-5

[44] Morrison, E.H.J., Banzaert, A., Upton, C., Pacini, N., Pokorny, J. and Harper, D.M. (2014) Biomass Briquettes: A Novel Incentive for Managing Papyrus Wetlands Sustainably? Wetlands Ecology and Management, 22, 129-141. https://doi.org/10.1007/s11273-013-9310-x

[45] Jones, M.B. (1983) Papyrus: A New Fuel for the Third World. New Scientist, 99, 419-421.

[46] MIT's D-Lab (2012). http://d-lab.mit.edu

[47] Banzaert, A. (2013) Viability of Waste-Based Cooking Fuels for Developing Countries: Combustion Emissions and Field Feasibility. Ph.D. Thesis, Massachusetts Institute of Technology, Cambridge.

[48] Maclean, I.M.D., Boar, R.R. and Lugo, C. (2011) A Review of the Relative Merits of Conserving, Using, or Draining Papyrus Swamps. Environmental Management, 47, 218-229. https://doi.org/10.1007/s00267-010-9592-1

[49] Cacciatore, M.A., Scheufele, D.A. and Shaw, B.R. (2012) Labeling Renewable Energies: How the Language Surrounding Biofuels Can Influence Its Public Acceptance. Energy Policy, 51, 673-682. https://doi.org/10.1016/j.enpol.2012.09.005

[50] Johnston, R., Cools, J., Liersch, S., et al. (2013) WETwin: A Structured Approach to Evaluating Wetland Management Options in Data-Poor Contexts. Environmental Science \& Policy, 34, 3-17. https://doi.org/10.1016/j.envsci.2012.12.006

[51] Rebelo, L.M., McCartney, M.P. and Finlayson, C.M. (2010) Wetlands of Sub-Saharan Africa: Distribution and Contribution of Agriculture to Livelihhoods. Wetlands Ecology and Management, 18, 557-572. https://doi.org/10.1007/s11273-009-9142-x

[52] Zsuffa, I., van Dam, A.A., Kaggwa, R.C., Namaalwa, S., Mahieu, M., et al. (2014) Towards Decision Support-Based Integrated Management Planning of Papyrus Wetlands: A Case Study from Uganda. Wetlands Ecology and Management, 22, 199-213. https://doi.org/10.1007/s11273-013-9329-Z

[53] Global Panel (2015) Improved Metrics and Data Are Needed for Effective Food System Policies in the Post-2015 Era. Global Panel on Agriculture and Food Sys- 
tems for Nutrition, London.

[54] IFPRI (International Food Policy Research Institute) (2016) Global Hunger IndexGetting to Zero Hunger. Washington DC/Dublin/Bonn.

[55] Robinson, S., Yùnez-Naude, A., Hinojosa-Ojeda, R., Lewis, J.D. and Devarajan, S. (1999) From Stylized to Applied Models: Building Multisector CGE Models for Policy Analysis. The North American Journal of Economics and Finance, 10, 5-38. https://doi.org/10.1016/S1062-9408(99)00014-5

[56] Dervis, K., de Melo, J. and Robinson, S. (1982) General Equilibrium Models for Development Policy. Cambridge University Press, New York.

[57] Arndt, C., Farmer, W., Strzepek, K. and Thurlow, J. (2012) Climate Change, Agriculture and Food Security in Tanzania. Review of Development Economics, 16, 378-393. https://doi.org/10.1111/j.1467-9361.2012.00669.x

[58] Diao, X. and Kennedy, A. (2016) Economywide Impact of Maize Export Bans on Agricultural Growth and Household Welfare in Tanzania: A Dynamic Computable General Equilibrium Model Analysis. Development Policy Review, 34, 101-134. https://doi.org/10.1111/dpr.12143

[59] Manning, D.T., Taylor, J.E. and Wilen, J.E. (2016) General Equilibrium Tragedy of the Commons. Environmental and Resource Economics, 69, 75-101.

[60] Winter, E., Faße, A. and Frohberg, K. (2015) Food Security, Energy Equity, and the Global Commons: A Computable Village Model Applied to Sub-Saharan Africa. Regional Environmental Change, 15, 1215-1227. https://doi.org/10.1007/s10113-014-0674-0

[61] Das, S., Muleba, M., Stevenson, J.C. and Norris, D.E. (2016) Habitat Partitioning of Malaria Vectors in Nchelenge District, Zambia. The American Journal of Tropical Medicine and Hygiene, 94, 1234-1244. https://doi.org/10.4269/ajtmh.15-0735

[62] Stevenson, J.C., Pinchoff, J., Muleba, M., Lupiya, J., Chilusu, H., Mwelwa, I., et al. (2016) Spatio-Temporal Heterogeneity of Malaria Vectors in Northern Zambia: Implications for Vector Control. Parasites \& Vectors, 9, 510. https://doi.org/10.1186/s13071-016-1786-9

[63] CSO (2016) 2015 Living Conditions Monitoring Survey Report. Republic of Zambia. Central Statistical Office, Lusaka, Zambia.

[64] IAPRI (2016) Rural Agricultural Livelihoods Survey. 2015 Survey Report. Indaba Agricultural Policy Research Institute, Lusaka, Zambia.

[65] UNDP (2013) Millennium Development Goads (MDGs). Provincial Profile/Luapula Province/2013. United Nations Development Programme, Lusaka, Zambia.

[66] Chidumayo, E.N. (2016) Classification of Forests in Zambia. Technical Report Series 2016. Technical Report No. 1, Lusaka, Zamiba.

[67] Leadley, P., Pereira, H.M., Alkemade, R., Fernandez-Manjarrés, J.F. Proenca, V., et al. (2010) Biodiversity Scenarios: Projections of 21st Century Change in Biodiversity and Associated Ecosystem Services. Technical Series No. 50, Secretariat of the Convention on Biological Diversity, Montreal, $132 \mathrm{p}$.

[68] Pohjonen, V.M. (2004) Zambia Forest Resource Assessment 2004. EU-Forestry Support Programme in Zambia-8 ACP/051, FRA Zambia 2004.

[69] Puustjärvi, E., Mickels-Kokwe, G. and Chakanga, M. (2005) The Contribution of the Forest Sector to the National Economy and Poverty Reduction in Zambia. Forestry Department, Zambia and Ministry for Foreign Affairs of Finland, Lusaka, Zambia.

[70] Vinya, R., Syampungani, S., Kasumu, E.C., Monde, C. and Kasubika, R. (2012) Pre- 
liminary Study on the Drivers of Deforestation and Potential for REDD+ in Zambia. A Consultancy Report Prepared for Forestry Department and FAO under the National UN-REDD+ Programme of Lands \& Natural Resources, Lusaka, Zambia.

[71] Syampungani, S., Chirwa, P.W., Akinnifesi, F.K., Sileshi, G. and Ajayi, O.C. (2009) The Miombo Woodlands at the Cross Roads: Potential Threats, Sustainable Livelihoods, Policy Gaps and Challenges. Natural Resources Forum, 33, 150-159. https://doi.org/10.1111/j.1477-8947.2009.01218.x

[72] (2017) Report of the Auditor General on Sustainable Forest Management Republic of Zambia.

[73] Lofgren, H., Harris, R.L. and Robinson, S. (2002) A Standard Computable General Equilibrium (CGE) Model in GAMS (Vol. 5). International Food Policy Research Institute.

[74] Rutherford, T.F. (1995) Extension of GAMS for Complementarity Problems Arising in Applied Economic Analysis. Journal of Economic Dynamics and Control, 19, 1299-1324. https://doi.org/10.1016/0165-1889(94)00831-2

[75] Bishop, P.M., Nicholson, C.F., Pratt, J.E. and Novakovic, A.M. (2001) Tariff-Rate Quotas: Difficult to Model or Plain Simple? Working Paper 2001/7, Institute of Economic and Research, New Zealand.

[76] Böhringer, C. and Rutherford, T.F. (2005) Integrating Bottom-Up into Top-Down: A Mixed Complementarity Approach. ZEW, Centre for European Economic Research Discussion Paper No. 05-028. https://doi.org/10.2139/ssrn.770725

[77] Carpenter, S.R., Cole, J.J., Pace, M.L., Batt, R., Brock, W.A., Cline, T., Coloso, J., Hodgson, J.R., Kitchell, J.F., Seekell, D.A., Smith, L. and Weidel, B. (2011) Early Warnings of Regime Shifts: A Whole-Ecosystem Experiment. Science, 332, 1079-1082. https://doi.org/10.1126/science.1203672

[78] Dirkse, S.P. (1994) Robust Solution of Mixed Complementarity Problems. A Thesis Submitted in Partial Fulfillment of the Requirements for the Degree of Doctor of Philosophy, University of Wisconsin, Madison.

[79] Brooke, A., Kendrick, D. and Meeraus, A. (1992) Release 2.25, GAMS, a User's Guide. The Scientific Press, San Francisco.

[80] Angelsen, A. (1999) Agricultural Expansion and Deforestation: Modelling the Impact of Population, Market Forces and Property Rights. Journal of Development Economics, 58, 185-218. https://doi.org/10.1016/S0304-3878(98)00108-4

[81] Armington, P.A. (1969) A Theory of Demand for Products Distinguished by Place of Production. IMF Staff Papers, 16, 159-178. https://doi.org/10.2307/3866403

[82] CSO (2016) National Accounts. Provincial Gross Domestic Product (GDP)-Charts. Industry Share to the GDP Ant Current Prices. Central Statistical Office, Republic of Zambia, Lusaka, Zambia.

[83] Davies, J.B. (2009) Combining Microsimulation with CGE and Macro Modelling for Distributional Analysis in Developing and Transition Countries. International Journal of Microsimulation, 2, 49-65.

[84] Layman, B. and Australia, W. (2004) CGE Modelling as a Tool for Evaluating Proposals for Project Assistance: A View from the Trenches. In: Fourth Biennial Regional Modelling Workshop in Melbourne: Policy Applications of Regional CGE Modelling, Melbourne, 1-25.

[85] Peichl, A. (2016) Linking Microsimulation and CGE Models. International Journal of Microsimulation, 9, 167-174. 
[86] Colombo, G. (2010) Linking CGE and Microsimulation Models: A Comparison of Different Approaches. International Journal of Microsimulation, 3, 72-91.

[87] Banda, O.O. (2013) Minimum Wage Policy and Domestic Workers in Zambia. Research Paper in Partial Fulfillment of the Requirements for Obtaining the Degree of Master of Arts in Development Studies, The Hague, The Netherlands.

[88] Holt, D. and Littlewood, D. (2017) Waste Livelihoods amongst the Poor-Through the Lens of Bricolage. Business Strategy and the Environment, 26, 253-264. https://doi.org/10.1002/bse.1914

[89] Gronau, S., Winter, E. and Grote, U. (2017) Modelling Nature-Based Tourism Impacts on Rural Development and Conservation in Sikunga Conservancy, Namibia. Development Southern Africa, 34, 276-294. https://doi.org/10.1080/0376835X.2016.1269638

[90] Chidumayo, E.N., Timberlake, J. and Sawadogo, L. (2010) Distribution and Characteristics of African Dry Forests and Woodlands. In: Chidumayo, E.N. and Gumbo, D.J., Eds., The Dry Forests and Woodlands of Africa: Managing for Products and Services, Earthscan, London, UK, 11-41.

[91] Bailis, R., Ezzati, M. and Kammen, D.M. (2005) Mortality and Greenhouse Gas Impacts of Biomass and Petroleum Energy Futures in Africa. Science, 308, 98-103. https://doi.org/10.1126/science.1106881

[92] Thenya, T. (2006) Analysis of Macrophyte Biomass Productivity, Utilization and Its Impact on Various Eco-Types of Yala Swamp, Lake Victoria Basin, Kenya. In: Denich, M., Martius, C. and Rodgers, C., Eds., Ecology and Development Series No. 48, Cuvillier-Verlag, Göttingen, 207.

[93] Klapwijk, C.J., van Wijk, M.T., Rosenstock, T.S., van Asten, P.J.A., Thornton, P.K. and Giller, K.E. (2014) Analysis of Trade-Offs in Agricultural Systems: Current Status and Way Forward. Current Opinion in Environmental Sustainability, 6, 110-115. https://doi.org/10.1016/j.cosust.2013.11.012

[94] Röttgers, D. (2016) Conditional Cooperation, Context and Why Strong Rules Work-A Namibian Common-Pool Resource Experiment. Ecological Economics, 129, 21-31. https://doi.org/10.1016/j.ecolecon.2016.03.013

[95] Peh, K.S.-H., Balmford, A., Bradbury, R.B., et al. (2013). TESSA: A Toolkit for Rapid Assessment of Ecosystem Services at Sites of Biodiversity Conservation Importance. Ecosystem Services, 5, 51-57. https://doi.org/10.1016/j.ecoser.2013.06.003

[96] Kateyo, E., Nsereko, P. and Kansiime, F. (2014) Contribution of Wetland Resources to Household Incomes of Riparian Communities of Katonga Wetland in Mpigi District, Uganda. International Journal of Sciences: Basic Applied Research (IJSBAR), 13, 274-286. 
Appendix A. Stylized Social Accounting Matrix of the Mantapala village*.

(a)

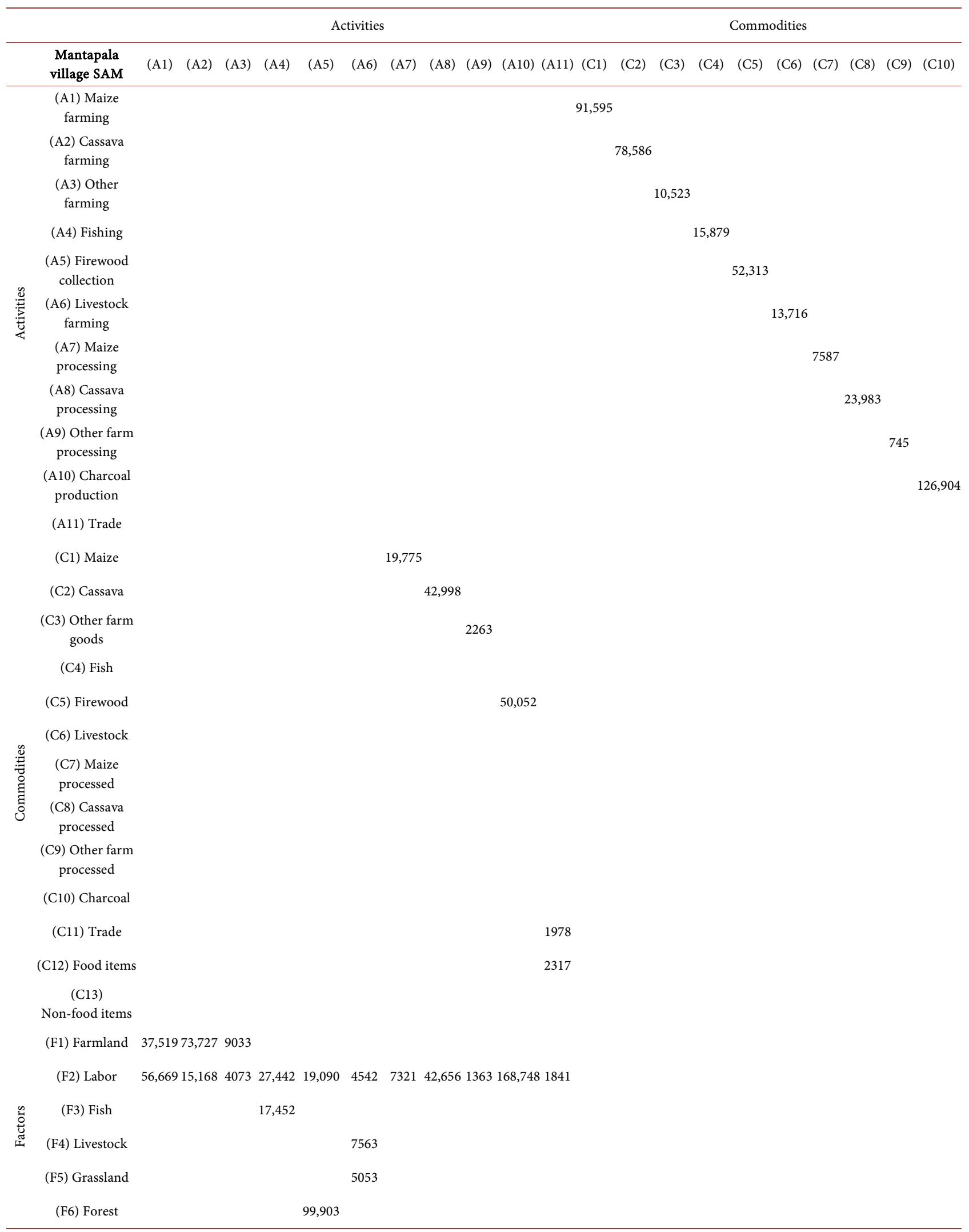




\section{Continued}

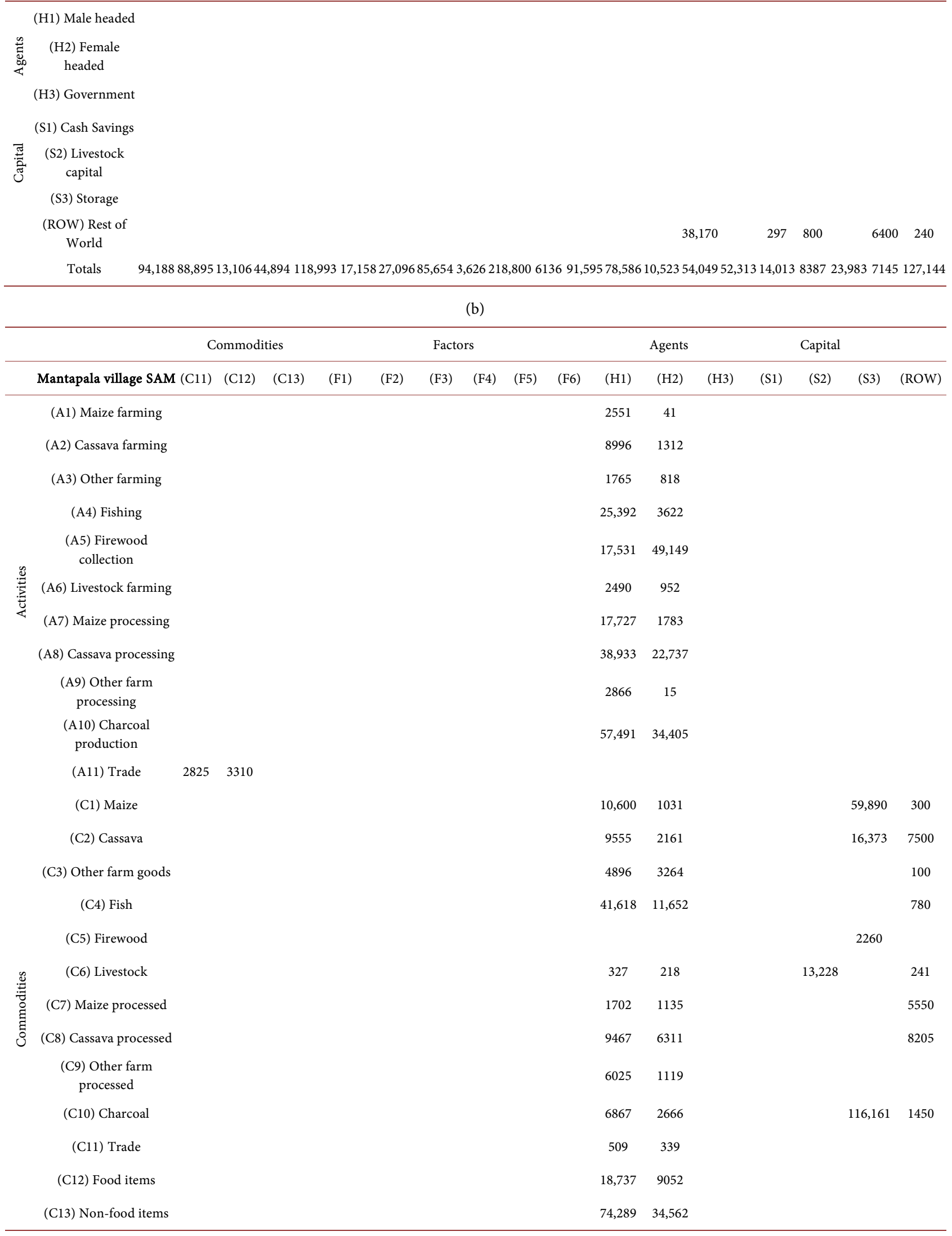




\section{Continued}

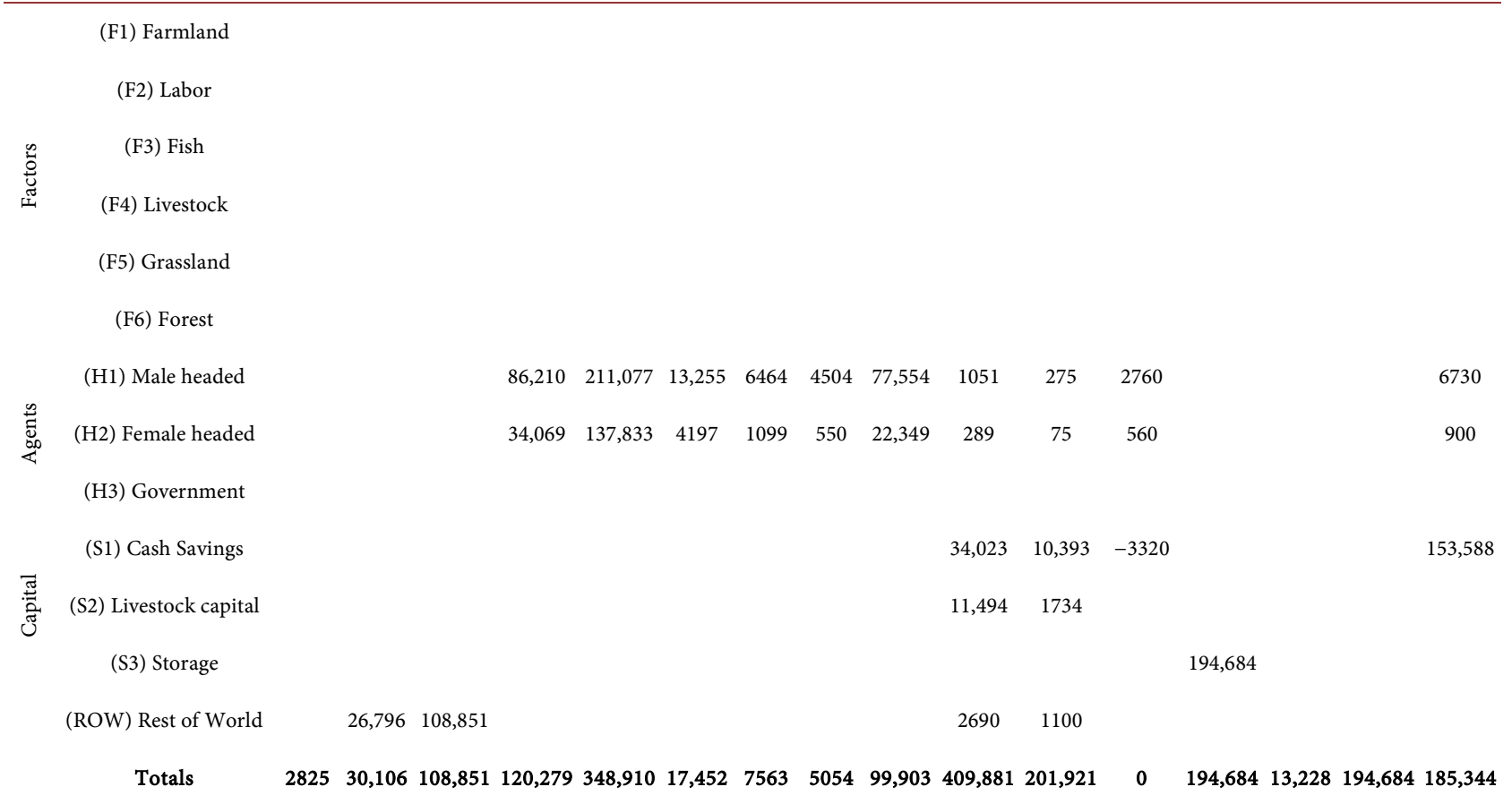

*Values reported in Zambian Kwacha (ZMK).

Appendix B. Input data of the bioenergy module for calibration and simulation.

\begin{tabular}{|c|c|c|c|}
\hline Parameter & Value & Unit & Reference \\
\hline \multicolumn{4}{|l|}{ Harvesting and processing papyrus: } \\
\hline Value of labor factor (harvesting) & 0.48 & ZMK per $5.33 \mathrm{~kg}$ & Own estimation \\
\hline Value of labor factor (processing) & 0.70 & ZMK per $5.33 \mathrm{~kg}$ & Own estimation \\
\hline Value of land factor & 2.55 & ZMK per $5.33 \mathrm{~kg}$ & Own estimation \\
\hline Value of papyrus raw & 0.57 & ZMK per $5.33 \mathrm{~kg}$ & $\begin{array}{l}\text { Own estimation using Kateyo et al. } \\
\text { [96] }\end{array}$ \\
\hline Value of cassava input (10\%) & 0.20 & ZMK per 0.116 kg & Own estimation \\
\hline Briquette output of $5.33 \mathrm{~kg}$ papyrus input & $1.16(48.3)$ & $\mathrm{kg}$ (briquettes) & [44] \\
\hline Value of papyrus briquettes & 3.92 & ZMK per $1.16 \mathrm{~kg}$ & $\begin{array}{l}\text { Own estimation using Morrison } \\
\text { et al. }[44]\end{array}$ \\
\hline Output of one papyrus briquette system & 1.16 & $\mathrm{~kg}$ & [44] [46] \\
\hline \multicolumn{4}{|l|}{ Energy demand (share of calorific value): } \\
\hline Male headed household (subsistence) & 48 & & \\
\hline Female headed household (subsistence) & 45 & & \\
\hline Male headed household (expenditure) & 4 & Percent & $\begin{array}{l}\text { Own estimation using Morrison et al. } \\
\text { [44] }\end{array}$ \\
\hline Female headed household (expenditure) & 2 & & \\
\hline Exports & 1 & & \\
\hline Balancing the module: & & & \\
\hline
\end{tabular}


S. Gronau et al.

\section{Continued}

Share of male households in factor income

Share of female households in factor income

Capital (savings) and current account balance

\section{Simulation:}

Operations per day per system

Operations per year with 4 systems
0.79

0.21

Percent

Own estimation

Residual

ZMK

Number

Own estimation

$2920(2)$

Number (\%GDP)

Own estimation 